GERŐ MÁRTON ${ }^{1}$ - HAJDU GÁBOR ${ }^{2}$

AZ EGYÉNI KAPCSOLATHÁLÓK NAGYSÁGA, HETEROGENITÁSA ÉS A TÁRSADALMI INTEGRÁCIÓ MAGYARORSZÁGON ${ }^{3}$

Dol: $10.18030 /$ socio.hu.2015.4.12

\title{
ABSZTRAKT
}

Tanulmányunk célja a társadalmi integráció, valamint az egyéni kapcsolathálók mérete és heterogenitása közti kapcsolat kérdéseinek és szakirodalmának felvázolása, valamint reprezentatív magyarországi adatfelvételek illusztratív célú másodelemzésével egy későbbi, részletesebb kutatás megalapozása. Ebben az elemzésben a társadalmi integrációt az egyének közti kooperatív viselkedésként és szolidaritásként definiáljuk, míg egy társadalmat dezintegráltnak tekintünk, amennyiben az általánosított (másokba vetett) bizalom, az intézményi bizalom és a normakövetés szintje alacsony, a tagjai közti szolidaritás gyenge. Egyéni szinten az integráltság az érzékelt vagy szubjektív integráltsággal, a dezintegráltság pedig az érzékelt társadalmi kirekesztettséggel ragadható meg.

Eredményeink szerint az egocentrikus kapcsolathálók mérete és heterogenitása pozitív kapcsolatban áll az integráció külső mércék alapján meghatározott (objektív) indikátoraival (részvétel, bizalom), míg a szubjektív integráltság esetében kevésbé egyértelmű és inkább fordított irányú vagy hiányzó a kapcsolat. Ezek az eredmények megerősítik, hogy kutatási kérdésünk további, mélyebb elemzésre érdemes.

Kulcsszavak: egocentrikus kapcsolatháló, társadalmi integráció, bizalom, részvétel

\section{EGOCENTRIC NETWORK SIZE, NETWORK HETEROGENEITY AND SOCIAL INTEGRATION IN HUNGARY}

\section{ABSTRACT}

In this paper, our aim is to describe the relevant problems and literature of the relationship between size and heterogeneity of the ego network and social integration. Moreover, as the first step of a subsequent, more detailed research, we wish to give an illustrative analysis about this relationship, using nationally representative databases from Hungary. On the one hand, we define social integration as cooperative behaviour of individuals and as solidarity between them. On the other hand, social disintegration is characterized with low levels of generalized and institutional trust, lack of solidarity and lack of norm conformity. At the individual level, integration can be defined as subjective integration, whereas disintegration is perceived as social exclusion from society.

Our results show that the size and heterogeneity of the egocentric network associated positively with external (objective) indicators of social integration (participation, trust), while the correlation between these variables and subjective integration is less clear and has an opposite direction or there is no correlation at all. These results confirm that our research questions deserve further, more detailed analysis.

Keywords: egocentric network, social integration, trust, participation

1 MTA TK Szociológiai Intézet; ELTE TÁTK; MTA-ELTE Peripato Kutatócsoport

2 MTA TK Szociológiai Intézet; MTA-ELTE Peripato Kutatócsoport

3 A tanulmány az Integrációs és dezintegrációs folyamatok a magyar társadalomban című OTKA kutatás (108836) keretében készült. 


\section{AZ EGYÉNI KAPCSOLATHÁLÓK NAGYSÁGA, HETEROGENITÁSA} ÉS A TÁRSADALMI INTEGRÁCIÓ MAGYARORSZÁGON

\section{BEVEZETÉS}

A társas kapcsolatokat gyakran kezelik az egyén (társadalmi) integráltságának indikátoraként. ${ }^{4}$ Az ezzel vagy legalábbis hasonló, a társadalmi státusz eléréssel, társadalmi tőkével, információk és újitások terjedésével, társas támogatással - foglalkozó tanulmányok rendszerint a kapcsolatok három jellemzőjét emelik ki:

a. Fontos, hogy az egyénnek legyenek kapcsolatai. A kapcsolathiány egyértelmúen a szegregáció, alulintegráltság jele (Albert-Dávid 2012).

b. Jól integráltnak tekinthetőek azok, akiknek heterogén (többféle csoportból rekrutálódó) kapcsolataik vannak, hiszen többféle hatás, információ juthat el az ilyen emberekhez és nagyobb esélyük van a felfelé irányuló mobilitásra is (Laumann 2006).

c. Előnyt jelent, ha az egyén kapcsolathálója nem csupán erős, baráti vagy családi kapcsolatokból áll. Ezek hatása a társas támogatásban rendkívül fontos, ugyanakkor a gyenge, távolabbi csoportokba mutató kapcsolatok segíthetnek az erőforrások hatékonyabb mozgósításában. Ennek jól ismert példái közé tartozik Granovetter (1973) gyenge kapcsolatok erejéről szóló tézise, Lin (1991, 1999) státusz-elérésre vonatkozó vizsgálatai vagy Angelusz és Tardos (1991a) tanulmánya, akik magyarországi adatok alapján jutottak arra, hogy a két kapcsolattípus egymás pozitív hatásait erősíti.

Az egyén tehát jól integráltnak tekinthető, ha vannak kapcsolatai, azok heterogének és egyaránt találunk közöttük erős és gyenge kötéseket is.

A társadalmi integrációnak ugyanakkor más indikátorait is érdemes figyelembe venni, hiszen a kapcsolathálózatokon keresztül csupán a társadalmi rendszerek egyik szféráját tudjuk megvizsgálni. Ugyanilyen fontos lehet a másokba vetett bizalom mértéke és az írott vagy íratlan normák elfogadottsága is. Az általánosított (másokba vetett) bizalom és a normakövetés azonban még mindig inkább az integráció informális és személyközi viszonyainak feltérképezésére alkalmas. Ezeken kívül a formális intézményekhez való viszonyt is figyelembe kell vennünk, amelyet az intézményekbe vetett bizalmon és a részvétel különböző formáin keresztül tudunk megközelíteni. Ezek a tényezők azonban az integráltság külső, kutatói döntés alapján meghatározott indikátorai, amelyek mellett érdemes olyan szubjektív indikátort is alkalmazni, ami az egyén személyes értékelését képes megragadni a saját integráltságával kapcsolatban. Az integráltság szubjektív értékelése szintén több tényezőből állhat össze. Az elismerés és elfogadás mindenképpen fontos eleme ennek, ahogy az is, hogy az egyén a külső körülmények által megkívánt cselekedetei és életmódja, valamint a saját értékrendje és céljai között harmóniát tapasztaljon meg. 
Tanulmányunkban egy folyamatban lévő kutatás exploratív részeként, a későbbi elemzések megalapozásaként magyar adatfelvételek másodelemzésével a kapcsolathálók integráló hatásával összefüggő elképzelések finomítására törekszünk. Egyrészt arra keressük a választ, hogy az egocentrikus kapcsolathálók mérete, illetve annak tagjai és a kapcsolatok típusa szerinti heterogenitása milyen kapcsolatban áll más, az integráció külső mércék alapján meghatározott (objektiv) indikátoraival és a szubjektíven érzékelt integráltsággal. Azt feltételezzük, hogy a zárt és homogén kapcsolathálók az ezekre jellemző erős társas támogatás és homogénebb világkép miatt akkor is az erős integráltság érzetét eredményezhetik, ha egyébként a társadalmi csoportok erősebb elkülönülését okozzák és akadályozzák a különféle erőforrásokhoz való hozzáférést, vagy az intézményekkel szembeni bizalmatlansághoz, ellenálláshoz, passzivitáshoz vezetnek.

Az alábbiakban elsőként definiáljuk az általunk használt fogalmakat (2. rész), majd röviden bemutatjuk az integráció indikátorainak és a személyes kapcsolathálók nagyságával és homogenitásával kapcsolatos eddigi, Magyarországra vonatkozó ismereteket. Ezután bemutatjuk a hipotéziseinket, valamint a kutatásunk szempontjából releváns szakirodalom vázlatos összefoglalására vállalkozunk. Mindezt kiegészítjük egy olyan, elsősorban illusztrációnak szánt elemzéssel, ami a jelenleg rendelkezésre álló hazai vagy nemzetközi kérdőíves kutatások adatbázisára épül, és amely a kutatási kérdéseink egy-egy szeletét érinti: az adatok és az elemzési stratégia leírása az 5. részben, az eredmények pedig a 6. részben találhatóak. Az utolsó részben a tanulmány rövid öszszefoglalását adjuk.

\section{FOGALMAK}

Integrált és dezintegrált társadalmak, az integráció indikátorai

Ebben az elemzésben a társadalmi integrációt az egyének társadalommal való azonosulásaként és kooperatív viselkedéseként, valamint az egyének közti szolidaritásként definiáljuk. A megközelítésünk szorosan kapcsolódik Banfield (1958) sokat hivatkozott munkájához, amelyben egy dél-olaszországi kisvárost vizsgálva írta le az „amorális familizmus” fogalmát, amivel az alacsony közéleti részvételt, gazdasági fejlődést és bizalmi szintet foglalta össze. Definíciója szerint „az amorális családközpontúság társadalmában senki sem mozdítja elő a csoport vagy a közösség érdekét kivéve, ha az a saját előnyére is válik" (Banfield 1958: 85). Az amorális familizmus társadalmi állapotnak tekinthető (Dupcsik-Tóth 2008), ami egy olyan társadalmat ír le, ahol a bizalom szintje alacsony, a közéleti aktivitás gyenge, az egyének pedig a saját érdekeiket követik a közösség érdekei helyett, és másokról is ezt feltételezik. Az ilyen társadalmakban a családba vetett bizalom a másokba vetett bizalomhoz képest igen magas, azaz az egyének a családtagjaikban bíznak elsősorban, míg másokkal szemben bizalmatlanok.

A társadalom integráltságát ennek megfelelően három dimenzióban ragadhatjuk meg. Az első a bizalom mértéke. Egy integrált társadalomban az egyének mind egymásban (általánosított bizalom), mind az intézményekben (például kormány, parlament, bíróság, rendőrség stb.) bíznak (intézményi bizalom). Alacsony általánosított és intézményi bizalom mellett az egyének azt feltételezik, hogy a társadalom többi tagja nem osztja az általuk vallott értékeket, nem várható másoktól kooperativ és kölcsönösen tisztességes viselkedés, így mindenki nagyobb valószínűséggel követi a saját érdekeit (Brann-Foddy 1987, Messick et al. 1983, Tyler-Degoey 1995). 
Az intézményekbe vetett bizalom a gazdasági és politikai rendszer legitimitása szempontjából is fontos:

„[a] bizalom a társadalmi és gazdasági rendszer müködésmódjának a helyeslését jelenti, valamint egy olyan társadalomlélektani mechanizmust, amely a rendszerben résztvevők társadalmi viselkedését is pozitiv módon befolyásolhatja, és kapocsként szolgál a személyes motivációk és hitvallások, illetve az elérni kivánt szervezeti és társadalmi célok között" (Csepeli et al. 2004: 3).

A második dimenzió a normakövetés, amely egyfelől az egyének saját normakövető magatartásaként értelmezhető, másfelől - a bizalommal szoros összefüggésben - a mások normakövető magatartásának értékeléseként, észleléseként. Ha valaki másokról normaszegő magatartást feltételez, az nem csak annak a jele lehet, hogy nem bízik másokban, hanem annak is, hogy valójában saját magával szemben is „megengedőbb” lehet, könnyebben szegheti meg a szabályokat. Az önérdekkövetés mindemellett a közösség érdekében végzett tevékenységek visszaszorulását is eredményezi (Cohen 1999, Putnam et al. 1993).

A harmadik dimenzió a közéleti, civil szervezeti részvétel. A köz ügyeivel való foglalkozás fogalmában már önmagában megjelenik a közérdeknek - legalább részleges módon - saját érdek elé helyezése. A civil aktivitás segíti a közfeladatot ellátó személyek ellenőrzését (Nárai 2004), ezzel ösztönzi a normakövetést és a korrupció csökkenését, a bizalomhiány és a közösséggel szembeni felelősségérzet hiánya pedig a társadalmi részvétel, a civil szervezetekben való aktív tevékenység alacsony szintjével jár együtt (Wollebaek-Selle 2002). Emellett régi feltételezés, hogy a civil szervezeti tagság hozzájárul a demokratikus politikai rendszerek, a társadalom integrációjához: egyrészt a civil szervezetek közvetítő szerepén, másrészt szocializációs hatásukon keresztül. Az előbbi esetben a civil szervezetekről azt feltételezik, hogy a szervezeti tagság összeköti a különböző társadalmi csoportokba tartozó egyéneket (Tocqueville 1993, Utasi 2013). A második feltételezett mechanizmus szerint a szervezetek tagjai megtanulják a demokratikus döntéshozatali technikákat, valamint elsajátítják azok sikeres alkalmazásához szükséges készségeket és normákat (Cohen-Arato 1992, Putnam et al. 1993, Tocqueville 1993, Utasi 2013). ${ }^{5}$

A három dimenzió önmagában is fontos eleme a társadalmi integrációnak, de egymással szorosan összefüggve, egymásra hatva együttesen képesek leginkább megragadni a társadalommal való azonosulásként, az egyének közötti szolidaritásként értelmezett társadalmi integráció jelenségét. A három dimenzió az integráltságot valamilyen funkció vagy hatás mentén ragadja meg, nem feltételezi azonban, hogy a vizsgált társadalom tagjai önértékelésük szerint is integráltak lennének. Márpedig feltételezhetően az az érzés, hogy a társadalom tagjai alapvetően a „helyükön vannak” hozzájárul az integrációt elősegítő mechanizmusok hosszú távú fennmaradásához, illetve megerősödéséhez is. Az integráltság szubjektív értékelését azon keresztül ragadjuk meg, hogy az egyén mennyire érzi magát biztonságban, mennyire érzi magát a társadalom részének, mennyire érzi úgy, hogy fontos tagja a társadalomnak. Ennek a megközelítésnek az az előnye, hogy lehetővé teszi az egyéni integráltság sokféle értelmezésének figyelembevételét (Diener et al. 2009), szemben az „objektív”, külső mércék alapján definiált társadalmi integráció fogalmával (bizalom, normakövetés, közéleti részvétel).

5 Ezen kívül akár különbséget lehet tenni az egyes szervezeti típusok között is. Feltételezhető, hogy a részvétel önmagában is erősíti a társadalmi integrációt, azonban az apolitikus szervezetekben való részvétel hatása gyengébb. 
A kapcsolatháló méretének és heterogenitásának mérése

A személyközi kapcsolathálókat nagymintás survey felmérésekben általában kétféle kérdéssel mérik fel: az erős kapcsolatokat az ún. névgenerátor módszerrel, amelyben különböző szituációkra kérdeznek rá és arra kérik a válaszadót, hogy nevezzen meg néhány (általában három vagy öt) embert, akihez az adott szituációban fordulna. ${ }^{6}$ Ezek után a megnevezettek - vagy közülük a legfontosabbak - életkorára, foglalkozására, az ismeretség forrására vagy más releváns információkra vonatkozó kérdéseket tesznek fel. A névgenerátor tehát alkalmas arra, hogy felmérje a szűkebb egocentrikus háló kiterjedtségét és heterogenitását.

Kevésbé alkalmas azonban a távolabbi, gyengébb, de adott esetben hasznosnak bizonyuló kapcsolatok felmérésére, ezért a névgenerátor módszert ki szokták egészíteni un. pozíciógenerátor kérdésekkel. Ebben az esetben nem szituációkra kérdeznek rá, hanem azt tudakolják meg a válaszadótól, hogy ismer-e bizonyos pozíciójú vagy foglalkozású embereket (például orvost, politikust, szakmunkást, újságírót). Gyakran arra is rákérdeznek, hogy amennyiben ismer ilyet, számíthat-e segítségre az illetőtől (Lin-Fu-Hsung 2001).

\section{A MAGYAR HELYZET}

A társadalmi integráció fent ismertetett három indikátorának rendszerváltás utáni magyarországi alakulásáról Hajdu (2012) adott áttekintést. A következőkben részben erre építve mutatjuk be a magyar helyzetképet. $^{7}$

Magyarország európai összehasonlításban alacsony a bizalom mértéke, mind az általánosított, mind az intézményi bizalom esetében (Dupcsik-Tóth 2008, Giczi-Sik 2009, Tóth 2009). Nemzetközi összehasonlító vizsgálatok alapján az elmúlt évtizedekben folyamatosan csökkent az intézményi bizalom. A 2000-es években például a parlamentbe vetett bizalom visszaesése - bár több másik európai országban is visszaesett - Magyarországon volt a legnagyobb mértékű (1. ábra). Az általánosított bizalom ezzel szemben elsősorban a rendszerváltás környékén és a 90-es években csökkent jelentősen, majd a 2000-es években viszonylag alacsony szinten stagnált.

6 A névgenerátor sem feltétlenül csak erős kapcsolatokat mérhet, hiszen a kapcsolat jellege függ a kérdésben megfogalmazott szituációtól. Marsden (2005) például arra hívta fel a figyelmet, hogy minél inkább hangsúlyozza a szituáció a társas támogatás (akár érzelmi akár anyagi) valamely formáját a megfogalmazott kérdés, annál kisebb méretű hálózat lesz az eredmény. Campbell és Lee (1991) vizsgálata ugyanakkor azt mutatta, hogy elsősorban a hálózat mérete változik, annak kompozíciója (azaz heterogenitása vagy a kapcsolatok jellege) kevésbé.

7 Ha máshogy nem jelezzük, a bizalom és a normakövetés magyarországi helyzetképéről tett megállapítások Hajdu (2012) tanulmányából származnak. 
1. ábra. A parlamentbe vetett bizalom változása 2002-2003 és 2008-2009 között európai összehasonlításban

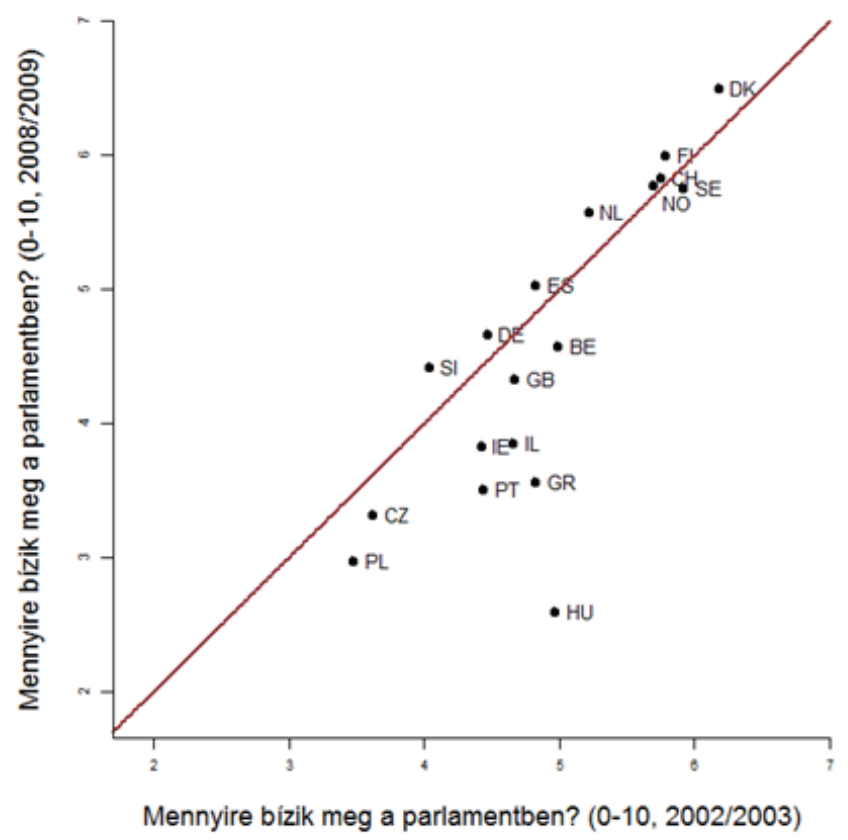

Az adatok forrása: European Social Survey (ESS) 1. és 4. hullám (Hajdu 2012: 50. alapján)

Megjegyzés: A piros (átlós) vonalon elhelyezkedő adatpontok esetében a parlamentbe vetett bizalom azonos a két időpontban.

A normakövetés/normaszegés dimenzióját vizsgálva hasonló eredményeket találunk. Egyfelől Magyarországon magas a normaszegés elítélése, ugyanakkor a vélemények polarizáltak: nagyon helytelenítők és az egyáltalán nem helytelenítők aránya egyaránt magas. Másfelől „a magyarok kétharmada (joggal vagy jogtalanul, nem tudjuk pontosan) úgy gondolja, hogy ő ugyan tisztességes, de a többiek nem” (Tóth 2009: 29), azaz „egy átlagos magyar” miközben magát együttmúködőnek (normakövetőnek) tartja, másokról normaszegő magatartást feltételez. Nemzetközi összehasonlításban szintén feltűnő, hogy Magyarországon jelentős a normaszegés elítélése, magas a normaszegő magatartásformák észlelése, viszont a saját normaszegő cselekvések bevallásának mértéke a vizsgált európai országok közül az egyik legalacsonyabb. 


\section{2. ábra: A normaszegés percepciója és a normaszegések elkövetésének bevallása európai összehasonlításban}

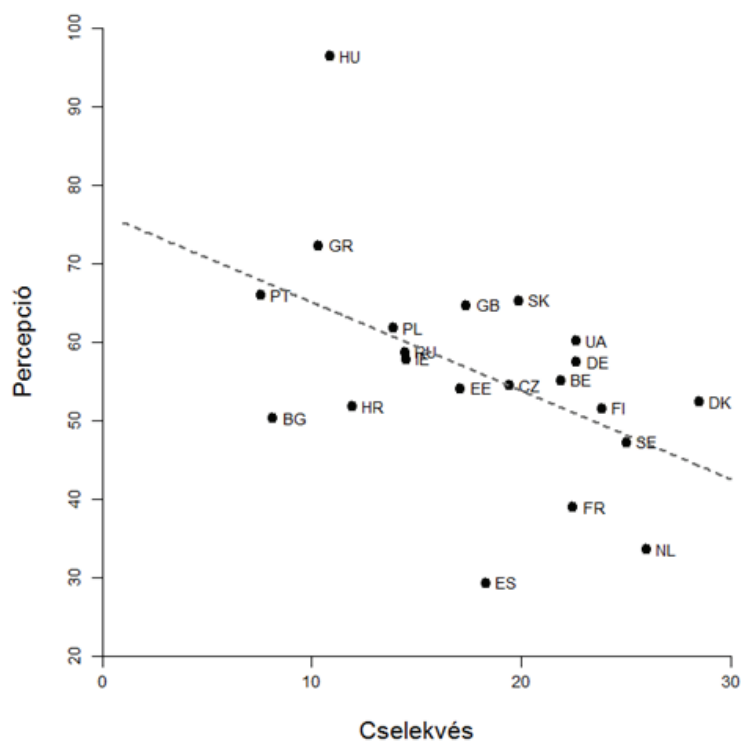

Az adatok forrása: European Values Study (EVS) 3. hullám (Percepció), European Social Survey ESS 5. hullám (Cselekvés) (Hajdu 2012: 56-57. alapján)

A civil társadalmi részvétel alakulásáról korábbi munkáinkban szót ejtettünk (Gerő 2012a; Hajdu 2012). Anélkül, hogy az adatokat a részletekbe menően újra ismertetnénk, általános tendenciaként érdemes kiemelni, hogy a részvétel szintje csökkent vagy stagnált az elmúlt 20-25 évben. Elsősorban a szakszervezeti és politikai szervezetekben való tagság visszaesése miatt az egyesületekben való részvétel mértéke az 1990-es években jelentősen lecsökkent, de ez a tendencia a 2000-es években is folytatódott. Az önkéntesség civil vagy vallási szervezetekhez, egyesületekhez, politikai pártokhoz kötődő formája a rendszerváltás óta a felnőtt lakosság egyre kisebb részét érinti a European Values Study adatai szerint. 1990-ben még 16,0\%, 2008-ban már csak 11,4 \%-uk végzett ilyen tevékenységet (EVS 2011). A tüntetésekben, petíciók aláirásában és az ehhez hasonló, inkább akciószerű, hosszabb távú szervezeti elköteleződést nem igénylő formákban való részvétel szintje jelentősen függött a megkérdezett tevékenységek számától, ugyanakkor a legtöbb részvételi formát felmérő kutatás szerint 1990 és 2010 között legfeljebb a 18 év felettiek 30 \%-a vett részt ilyen tevékenységekben (Gerő 2012a). Ezek közül népszerübbek a helyhez, időhöz kevésbé kötött formák, például a bojkott vagy bizonyos árucikkek elvi, ideológiai okokból történő vásárlása (pl. magyar vagy fair trade termékek) a kevesebb energia-befektetéssel járó petíciók aláirása, valamint a politikusokkal, szakértőkkel történő kapcsolatfelvétel.

A magyar kapcsolathálózatok alakulásának tendenciáit több írás is összefoglalja (Albert-Dávid 2003, 2007, 2012; Gerő 2012b), ezért itt csupán a legjellemzőbb tendenciákról teszünk említést. A kapcsolathálózatok vizsgálatát több módszerrel végzik, így az eredmények is eltérőek lehetnek.

Az erős kapcsolatokat illetően módszertől függetlenül azonos tendenciákat tapasztaltak a kutatók: ${ }^{8}$ az 1980-as évek végén, 1990-es évek elején körülbelül a felnőtt népesség egyharmada- ami nemzetközi összehasonlításban is magasnak számít - számított izoláltnak, azaz kevés (maximum négy) bizalmas kapcsolatot em- 
lítettek, vagy egyáltalán nem volt barátjuk. (Albert-Dávid 2012, Utasi 1991). Ez alól a kilencvenes évek eleje jelentett kivételt, amikor a kapcsolathálózatok hirtelen bővülését mérték a vizsgálatok. A kapcsolathálók ráadásul még a 80-as években mérthez képest is szúkültek az 1990-es években és a 2000-es évek elején. Ez a rokonok számának a kapcsolathálózaton belüli arányának növekedésével járt (Angelusz-Tardos 1998). ${ }^{9}$ A nem rokoni kapcsolatok, barátok elsősorban a munkahelyekről kerültek ki. A 2000-es évek második felében a teljes népességre jellemző bővülés és a kapcsolati struktúra átrendeződése figyelhető meg. A barátok átlagos száma például az 2004-es 4,2-es értékéről 5,5-re emelkedett. A legjelentősebb változás azonban a rokonok arányának drasztikus csökkenése a kapcsolathálózatokban, ami együtt jár a kapcsolatok nem szerinti homogenizációjával és azzal, hogy a házastársak, partnerek helyett a barátok veszik át a legfőbb bizalmas szerepét. A baráti kapcsolatok (nem rokoni erős kötések) forrása továbbra is elsősorban a munkahely, másodsorban az iskola (Albert -Dávid 2012).

A gyenge kapcsolatokat illetően nem rendelkezünk a rendszerváltozás óta eltelt időszakot felölelő longitudinális vizsgálatokkal: csupán Angelusz Róbert és Tardos Róbert foglalkozott ezek mennyiségi változásaival egy 1998-as tanulmányukban, ahol az 1990-es évekre vonatkozóan az erős kapcsolatokhoz hasonlóan a gyenge kapcsolatok mennyiségének csökkenését állapították meg (Angelusz-Tardos 1998). Összességében a magyar kapcsolathálózatok nemzetközi összehasonlításban viszonylag kisméretűnek, és mind iskolai végzettség, mind a rokonok arányát tekintve homogénnek túnnek.

A magyar politikai szociológiában már szinte közhely a kapcsolathálózatok politikai szempontok szerinti tömbösödésének tézise, amit tulajdonképpen minden erre irányuló kutatás megerősít. A 2000-es években az egyéni kapcsolathálók egyre inkább pártszimpátia szerint homogenizálódtak, elsősorban az egyes pártokat elkötelezetten támogató választók esetében (Angelusz-Tardos 2011). Újabban kevésbé vizsgált kérdés a társadalmi csoportokon átívelő kapcsolatok jelensége. A 80-as évek végén lezajlott kulturális és interakciós rétegződésvizsgálat a magyar társadalom presztízselv szerint szerveződését tárta fel: eszerint az alsó társadalmi rétegek felől a felső rétegek felé mutató kapcsolatok jellemzőek, míg a magasabb státuszú csoportokból az alacsonyabb felé mutatóak kevésbé gyakoriak (Angelusz-Tardos 1991c).

\section{HIPOTÉZISEK ÉS SZAKIRODALOM}

Az alábbiakban a korábbi kutatási eredmények alapján röviden áttekintjük a kapcsolathálózatok szerkezete, az objektív és szubjektív indikátor-csoportok közötti kapcsolatok jellemzőit. Ezek alapján fogalmazunk meg három hipotézist a magyarországi helyzetre vonatkozóan.

\section{Kapcsolatháló és bizalom}

A sűrú kapcsolathálók fontos szerepet játszanak a társadalmi kohézió és a magas bizalmi szint létrejöttében (Putnam 2000). Coleman (1990) szerint a sűrű kapcsolatháló fontos elem a mások megbízhatóságáról hozott egyéni döntéseknél. Azokban az esetekben, amikor valakinek egy másik személy megbízhatóságáról nincsenek közvetlen információi, az adott személlyel kapcsolatban álló ismerősei véleményére tud támaszkodni. Továbbá: ha mindenki ismer mindenkit, a személyes kapcsolatok, elköteleződések és leköteleződések nö- 
velhetik a bizalmat és csökkenthetik a nem kooperáló viselkedések előfordulását. A kapcsolatok száma mellett azok sokfélesége is fontos lehet: az egyének különbözőségét és sokféleségét megtapasztalók jobban bízhatnak másokban, kevésbé válhatnak előítéletessé, valamint a csoportközi konfliktusok gyakorisága is alacsonyabb lehet ilyen környezetben (Allport 1999).

Egyes kísérleti szituációkon alapuló kutatások szerint az egyének közötti közvetlen interakciók gyakorisága jó előrejelzője az egymás iránti bizalomnak (Pentland 2014). Egy Japánban végzett kutatás szerint pedig az egyéni kapcsoltháló diverzitása a férfiak között pozitív és szignifikáns kapcsolatban áll az általánosított bizalommal, ugyanakkor a kutatók a nők esetében nem találtak szignifikáns hatást (Miyata-Ikeda-Kobayashi 2008). A szerzők magyarázata szerint mivel a nők kapcsolathálója kevésbé volt heterogén, mint a férfiaké, így feltehetően nem volt elég diverz ahhoz, hogy növelje a bizalom mértékét.

\section{Kapcsolatháló és normakövetés}

A sűrű kapcsolathálók az erősebb társadalmi kontroll révén elősegíthetik a normák kikényszerítését (Coleman 1990). Ha az egyének ismerik egymást, akkor tudnak egymással szemben erkölcsi elvárásokat megfogalmazni, egymásra társadalmi nyomást helyezni. A gyakorlatban ezt használják ki például a mikrohitelek esetében is (Banerjee-Duflo 2007, Hermes-Lensink 2007, Sengupta-Aubuchon 2008). Ezeknél a hiteleknél a hitelfelvevők csoportokat alkotnak, és egy időben csak a csoport egyes tagjai kapnak hitelt. Ha ezek a személyek nem fizetik pontosan a részleteket, akkor a többi csoporttag nem vagy nehezebben kap hitelt. Ez a módszer az elmélet szerint a monitorozás és a társak kényszerítő hatása miatt csökkenti a normaszegések (a visszafizetés elmaradásának) előfordulási gyakoriságát. További hasonló hatása van a rendszeres csoporttalálkozóknak is, ami a csoporttagok közötti kapcsolatokat erősíti, és egyes eredmények szerint ezek az erősebb kapcsolatok és az egymás iránt érzett felelősségérzet a normakövetés kulcsa.

Karlan (2007) egy perui mikrohitel-program kvázi véletlenszerúen létrehozott csoportjainak adatait használva jutott arra az eredményre, hogy azok a csoportok, ahol erősebbek a csoporttagok közötti kapcsolatok, jobb törlesztési arányokat mutatnak. Egy másik, már említett kísérleti kutatás szerint pedig az egyének közötti interakciók gyakorisága nem csak a bizalom szintjével van kapcsolatban, hanem a csoportnyomás (peer pressure) hatékonyságával is (Pentland 2014).

A kapcsolatháló heterogenitása és a normakövetés közti kapcsolatot a következők alapján feltételezhetjük- A többféle társadalmi helyzetű embereket ismerők személyes tapasztalattal rendelkeznek a sajátjuktól eltérő nézőpontokról, így kevésbé előítéletesek és kevésbé sztereotip gondolkodásúak, következésképpen kevésbé kitettek csoportközi konfliktusoknak (Allport 1999). Ezzel párhuzamosan elképzelhető, hogy ezáltal a személyes felelősségérzet, a normák betartásának kötelezettsége az egyénhez hasonlókra kiterjedők csoportján túl egy szélesebb csoporton belül is érvényessé válik.

\section{Kapcsolatháló és közéleti részvétel}

Mind a nemzetközi, mind a hazai vizsgálatok bőséges empirikus anyaggal szolgálnak arról, hogy a kapcsolatháló mérete pozitív kapcsolatban van a részvétel legtöbb formájával (Bekkers-Völker-van der Gaag-Flap 
2008). Angelusz és Tardos (2003) a magyar országgyúlési és önkormányzati választások esetében is azonosította a kapcsolatháló mérete és a választáson való részvétel közötti összefüggést. Angelusz és Tardos (2005) másik tanulmánya szerint még jelentősebb ennek a tényezőnek a szerepe a civil szervezeti aktivitás és a különböző, szervezethez nem feltétlenül kötődő részvételi formák esetén. A 2013-as Hungarostudy adatai alapján végzett elemzés szerint a kapcsolatháló mérete továbbra is erős kapcsolatban áll a civil szervezeti részvétellel (Susánszky-Gerő 2013). Ugyanakkor érdemes kiemelni, hogy a kapcsolat iránya nem tisztázott: elképzelhető, hogy a nagyobb kapcsolathálózat fenntartásának egyik módja a részvétel, de az is, hogy a nagyobb ismerősi körrel rendelkezőket könnyebben vonják be a különböző szervezetek munkájába és az egyéb részvételi formákba.

Bonyolultabb kérdés, hogy a kapcsolatháló heterogenitása és a kapcsolatok típusai milyen hatással lehetnek a közéleti részvételre. Ugyan a demokratikus részvétel sok helyen megfogalmazott normatív szempontjai szerint az lenne kívánatos, ha az emberek heterogén hálózatokat építenének és különböző társadalmi helyzetú csoportok tagjaival vitatnák meg véleményüket, a „like-me" elv ${ }^{10}$ mellett több tényező is ennek ellenében hathat (Laumann 2006). A konfliktuskerülés vagy a véleményütköztetés miatti stressz ahhoz vezethet, hogy hasonló véleményű emberekkel próbáljuk meg körülvenni magunkat. Több kutatás szerint a heterogén kapcsolatháló inkább csökkenti, mintsem növeli a választáson való részvételt (Kmetty 2012). Ennek okát Mutz (2002) abban látja, hogy a többféle vélemény ismerete elbizonytalaníthatja a választót, míg Noelle-Neumann (2007) szerint túl sok ellenkező véleményű ismerős társaságában a normát jelentő véleményektől eltérőnek érezhetjük a saját nézeteinket. Coleman (1990) szerint a zárt, homogén csoportok képesek a választási részvétel növeléséhez szükséges társas támogatást biztosítani.

A klasszikus feltételezések abba az irányba mutatnak, hogy a civil szervezetek kapcsolatokat hoznak létre különböző társadalmi csoportok között, vagy azért, mert a szervezet tagsága heterogén, vagy azért, mert a különböző társadalmi csoportok szervezetei az érdek-artikuláció és érdekérvényesítés folyamatában kapcsolatba lépnek egymással. ${ }^{11}$ Ugyanakkor több tanulmány utal arra, hogy ez nem feltétlenül van így. Pichler és Wallace (2008) összehasonlító vizsgálata szerint a civil szervezeti tagság a társadalmi tőke képzésének egyik módja, ezért a magasabb státuszú csoportok tagjai inkább egymással, semmint az alacsonyabb státuszú csoportok tagjaival hoznak létre civil szervezeteket. Ez elvileg nem zárja ki azt, hogy a civil szervezetek tagjai heterogén kapcsolathálózatokat tartsanak fenn, ugyanakkor a szervezetekben létrejövő kapcsolatokba fektetett energia a más típusú kapcsolatok fenntartásának rovására mehet.

A civil részvételt általában is vizsgáló kutatások Magyarországon is arra utalnak, hogy a civil szervezetben résztvevők csoportja inkább homogénnek tűnnek: annak tagjai jobban különböznek a civil szervezetekben nem résztvevők csoportjától, mint egymástól (Susánszky-Gerő 2013, Utasi 2013), ami arra utal, hogy a civil részvétel elsősorban a homogén kapcsolatokat erősíti meg. A civil szervezetekben részt vevők csoportjában nagyobb arányban találunk férfiakat, fiatalabbakat, magasabb iskolai végzettségúeket. Emellett családjuk egy főre jutó jövedelme is magasabb, jobbnak értékelik egészségi állapotukat és úgy túnik, hogy inkább autonóm, magabiztos személyiséggel rendelkeznek, de kevésbé stresszesek, mint a nem civilek, és több baráttal rendelkeznek.

10 A más néven hasonlósági elvnek nevezett jelenség szerint az egyének a hozzájuk hasonlóakkal hoznak létre kapcsolatokat. 11 Lásd például: Putnam (1993) 
Sik (2010) szerint a heterogén kapcsolathálózatok jelentik a leginkább megfelelő talajt az állampolgári részvételhez szükséges kommunikativv, deliberativ készségek elsajátításához. A kapcsolathálózat heterogenitása így a demokratikus részvételhez szükséges kommunikatív racionalitás kialakításához járul hozzá, és közvetetten befolyásolja a tényleges részvételt és állampolgári attitúdöket, irányuljon az kifejezetten a civil társadalom, vagy a közhatalom felé. Más kutatások, amelyek elsősorban gyenge kötéseket vizsgáltak, viszont pozitív kapcsolatot találtak az egyéni kapcsolatháló heterogenitása és a civil szervezetekben való részvétel között. Magee (2008) két amerikai megyében (county) végzett kutatásában azt találta, hogy a pozíciógenerátorral mért egyéni kapcsolathálózati diverzitás pozitív kapcsolatban van a kérdezést megelőző 12 hónapban 12 különböző szervezetbe és aktivitásokba való bevonódással mért civil részvétellel. Egy japán kutatás hasonló eredményt talált. Szintén pozíciógenerátorral mérték a kapcsolatháló diverzitását, ami pozitív kapcsolatban állt az 5 különböző témával kapcsolatos civil aktivitással (Miyata et al. 2008).

\section{Kapcsolatháló és a szubjektív integráltság}

A zárt, homogén egocentrikus hálózatokkal rendelkezők többek között azért érezhetik biztonságban magukat, illetve azért tekinthetnek magukra integráltként, mert az erős kapcsolatok egyik legfontosabb funkciója a társas támogatás: nem csupán a „kézzel fogható” segítségnyújtás, hanem a lelki támasz és a vélemények megerősítése is elsősorban ezekhez a kötésekhez kapcsolódik (Albert-Dávid 2007, Angelusz-Tardos 1991b). Az erős kötések gyakran a „like-me” elv alapján jönnek létre, azaz elsősorban hasonló emberekkel kerülünk szorosabb kapcsolatba (Laumann 2006). Emellett az erős kötések jellemzően tranzitívak is: egy ego két erős kapcsolata nagyobb eséllyel ismeri meg egymást, mint két gyenge kötéssel kapcsolódó ismerőse (Granovetter 1983). Amennyiben a "like-me" elv igaznak bizonyul, nagy eséllyel két közeli ismerősünk is hasonlít egymásra, és közöttük is inkább erősebb, mint gyengébb kötés alakíthat ki, ami a szoros kapcsolatháló bezáródásához és homogenizálódásához vezethet. A hasonló ismerősökből álló hálózatban azonban folyamatos támogatásban és megerősítésben lesz részünk, ami egyre erősíti a már kialakult csoportot, így egyre nehezebb lesz új, a csoporttól eltérő ismerősöknek közel kerülni hozzánk. ${ }^{12}$

Bár a magyar szakirodalom elsősorban a hasonlóságon és az ebből fakadó vonzalmon alapuló mechanizmusokra épít, Skvoretz (2013) szerint a távolságtartás mechanizmusa legalább ilyen fontos. Homogén csoportok nem csupán a hasonlóhoz való vonzódással, hanem a különböző csoportoktól való távolságtartás okán is létrejöhetnek. Különösen fontos lehet ez a lakóhelyi vagy az etnikai szegregáció kialakulásában. A vonzás és taszítás mechanizmusai Skvoretz (2013) szerint más és más tényezők esetén játszhatnak fontos szerepet. Míg inkább a vonzás kaphat szerepet azon dimenziók esetében, amiket teljesítményen alapulónak gondolunk (pl. iskolai végzettség), addig a taszítás hatása jelentősebb lehet a személyiség részeként elképzelt (faji, vallási) változók esetén. A szubjektív integráltság, a biztonságérzet növekedését mindkét esetben feltételezhetjük, csupán annak okai lehetnek mások: míg az egyik esetben a társas támogatás, a folyamatos megerősítés, a másik esetben a „mások”-ról alkotott negatív kép és az ebből eredő félelem állhat a háttérben.

12 Ugyanakkor a hasonlósági elvet ellensúlyozza a már korábban említett presztízs-elv, ami arra a törekvésre utal, hogy magasabb társadalmi státuszú, más erőforrásokat mozgatni képes emberekkel kerüljünk kapcsolatba, ami pedig a sikeresség, az előrelépés és a mobilitás lehetőségét veti fel (Laumann 2006). 
Az áttekintett szakirodalom alapján úgy túnik, a kapcsolatháló mérete és összetétele (heterogenitása vagy homogenitása) egyaránt hatással lehet a társadalmi integrációra. Mindezek alapján a következő hipotéziseket fogalmazhatjuk meg:

H1. Ha az egyéni kapcsolatháló inkább rokoni kapcsolatokból áll, az egyén szubjektíven érzékelt integráltsága magasabb, miközben a társadalmi integráció (bizalom, normakövetés, részvétel) szintje alacsonyabb lehet. Másfelől, a heterogén kapcsolatháló pozitív kapcsolatban áll az általánosított bizalom mértékével, a normakövetéssel és a közéleti részvétellel, miközben az ilyen kapcsolathálóval rendelkező egyének kevésbé érezhetik magukat biztonságban.

H2. A kapcsolatháló mérete pozitív kapcsolatban áll a társadalmi integráció indikátoraival.

\section{ADATOK ÉS MÓDSZEREK}

Az elemzéshez a Magyar Választáskutatási Panel, valamint a European Quality of Life Survey 2. hullámának magyar adatait használtuk.

A Magyar Választáskutatási Panel kutatás keretében 3 közvélemény-kutató cég részben átfedő kérdőívekkel készített összesen 3300 fős adatfelvételt 2008-ban. ${ }^{13}$ Az egyéni kapcsolathálóra vonatkozó kérdések csak két kérdőívben szerepeltek, így a kiinduló mintánk elemszáma 2120 volt.

A társadalmi integráció általunk definiált indikátorai közül a kérdőív a civil szervezeti és közéleti aktivitásra, a választási részvételre és az intézményekbe vetett bizalomra vonatkozóan tartalmazott kérdéseket. A válaszadóknak 10 szervezetre vonatkozóan kellett megmondaniuk, hogy tagjai-e az adott típusú szervezetnek (például sportklubnak, szakmai társaságnak, karitatív szervezetnek, szakszervezetnek stb.). Az első indikátorunk (egyesületi, szervezeti tagság) azt mérte, hogy a válaszadó valamelyik felsorolt szervezetnek tagja-e.

A következő indikátorunk a közéleti aktivitás volt. A kérdőívben összesen 13 közügyekkel kapcsolatos cselekvésről, fellépésről kellett a válaszadóknak megmondaniuk, hogy a kérdezést megelőző néhány évben előfordult-e velük, hogy valamelyiket megtették. A lista meglehetősen széleskörű volt: a politikai szervezet, mozgalom munkájában való részvételtől kezdve, a tüntetésen való részvételen át, a tévémúsorhoz kapcsolódó sms-szavazásig tartott. ${ }^{14}$ A közéleti aktivitást mérő indikátorunk azt mérte, hogy a válaszadó a 13 közül bármiIyen módon részt vett-e a közügyek intézésében. Az előzőekhez kapcsolódva harmadik indikátorunk azt mérte, hogy a kérdezett részt vett-e a 2006-os országgyúlési választások két fordulója közül legalább az egyiken.

A negyedik és ötödik indikátorunk az állami intézményekbe, illetve a nem kormányzati szervezetekbe vetett bizalom volt. Összesen nyolc állami (kormány, bíróságok, parlament, alkotmánybíróság, hadsereg, köz-

$13 \mathrm{Az}$ adatbázis részletes leírása: http://www.tarki.hu/cgi-bin/katalogus/tarkifo_hun.pl?sorszam=TDATA-H27

14 A 13 közügyekkel kapcsolatos cselekvés a következő volt: Kapcsolatba lépett politikussal vagy önkormányzati képviselővel; Tevékenykedett egy politikai pártban, részt vett a rendezvényein; Részt vett más politikai szervezet vagy politikai mozgalom munkájában; Viselt vagy kihelyezett politikai jelvényeket, jelképeket; Tiltakozó levelet, petíciót írt alá; Részt vett törvényes, nyilvános tüntetésen (demonstráción); Szándékosan nem vásárolt, bojkottált bizonyos árucikkeket; Elvi okból vásárolt bizonyos árucikkeket (politikai, etikai, környezetvédelmi megfontolásból); Pénzt adományozott egy politikai szervezetnek vagy csoportnak; Részt vett nem engedélyezett tiltakozó megmozduláson; Újságcikket vagy hozzászólást írt valamilyen ügyben; Telefonos rádiómúsorba betelefonált; Sms-ben szavazott vagy hozzászólt valamelyik tévéműsorhoz 
társasági elnök, rendőrség, helyi önkormányzat) és négy nem kormányzati szervezet (egyházak, politikai pártok, szakszervezetek, civil szervezetek) esetében kellett megmondaniuk a válaszadóknak, hogy mennyire bíznak bennük (4 fokú skálán). Az állami intézményekbe, illetve a nem kormányzati szervezetekbe vetett bizalom változóit ezen válaszok átlagaként hoztuk létre. ${ }^{15}$

Ebben a kutatásban az erős kötéseket a névgenerátor módszerrel mérték: összesen három szituáció esetében (fontos dolgok megbeszélése; közös program; háztartás körüli teendők, mindennapi gondok megoldása) kérdeztek rá arra, hogy a válaszadó kikhez fordulhatna. Mindegy szituációnál 5-5 embert - összesen tehát legfeljebb 15 embert - nevezhettek meg a válaszadók, akikről azt is meg kellett mondaniuk, hogy milyen kapcsolatban vannak velük. Az erős kötések számát az itt megnevezett személyek számával mértük, és a kérdezett, valamint a felsorolt személyek közti kapcsolatra vonatkozó információ alapján a rokonok (házastársak, gyerekek, szülők, testvérek és egyéb rokonok) erős kötések közti arányát is meg tudtuk határozni.

A kérdőív tartalmazott pozíciógenerátor kérdéseket is, amelyekkel arra kérdeztek rá, hogy a válaszadó személyesen ismer-e különböző foglalkozású embereket. Összesen 22 foglalkozásra vonatkozóan szerepelt ilyen kérdés. A gyenge kötések számát a válaszadó által személyesen ismert foglalkozások számával mértük. Minden foglalkozáshoz a Treiman-féle Standard International Occupational Prestige Scale (SIOPS) 22 foglalkozásra vonatkoztatott rangszámát rendeltük hozzáa ${ }^{16}$, majd a rangszámok szórásaként definiáltuk a gyenge kötések heterogenitását.

A European Quality of Life Survey ${ }^{17}$ négyévente lebonyolított adatfelvétel, mely európai országokban vizsgálja a lakosság objektív és szubjektív életkörülményeit. A 2007-es, 2. hullám magyar adatfelvétele 1000 fős mintán valósult meg. Ebben a kérdőívben a válaszadók szubjektív integráltság-érzetére (társadalmi kirekesztettség érzetére) vonatkozó kérdések is szerepeltek. A kérdezetteknek a következő négy állitásról kellett megmondaniuk, hogy mennyire értenek velük egyet (5 fokú skálán).

d. Úgy érzem, hogy kitaszít a társadalom.

e. Az élet olyan bonyolulttá vált, hogy alig találom az utam.

f. Nem érzem úgy, hogy az emberek, akikkel találkozom, felismernék az értékét annak, amit csinálok.

g. Néhány ember lenéz engem munkahelyi helyzetem vagy jövedelmem miatt.

A szubjektív integráltság mutatóját a négy válasz összegeként hoztuk létre. A mutató magas értékei az állítások elutasítását, tehát az integráltságot, vagy másképp fogalmazva a társadalomból való kirekesztődés hiányát jelzik.

A kérdőívben az egyéni kapcsolathálóra vonatkozó kérdések hiányoztak, illetve meglehetősen elnagyoltak voltak. Az erős kötések számának és azokon belül a rokoni kapcsolatok arányának a mutatóját csak ezekből a kérdésekből tudtuk létrehozni, így azok távol álltak a tökéletestől. A válaszadóknak összesen öt szituáció esetében kellett megmondaniuk, hogy kitől kaphatnának segítséget az adott helyzetben (például ha a segítség-

15 Ha legalább négy állami intézményt, illetve legalább három nem kormányzati intézményt értékelt a válaszadó. 16 A rangszámok létrehozásához szükséges adatokért hálásak vagyunk Kmetty Zoltánnak.

17 European Foundation for the Improvement of Living and Working Conditions, European Quality of Life Survey, 2007 [computer file]. Colchester, Essex: UK Data Archive [distributor], October 2009. SN: 6299, http://dx.doi.org/10.5255/UKDA-SN-6299-1. 
re van szükségük, amikor munkát keresnek): partnerüktől/házastársuktól, egyéb családtagjuktól, kollégájuktól, barátjuktól, szomszédjuktól, valaki mástól vagy pedig senkitől. Az erős kötések számát azzal mértük, hogy az öt szituációból hány esetben kaphatnak segítséget valakitől, ezen belül a rokonok erős kötések közötti arányát mérő változót a partner/házastárs vagy az egyéb családtag említési arányaként hoztuk létre. A gyenge kötésekre vonatkozó kérdés nem szerepelt a kérdőívben.

Az integráció indikátorai és az egyéni kapcsolatháló mutatói közti kapcsolatot lineáris regressziós modellekkel becsültük. A kétértékű változók esetében ezek lineáris valószínúségi modelleket jelentenek, azonban a becsléseket logit modellekkel is elvégeztük, ami nem változtatott a levonható következtetésen. Az eredmények egyszerúbb értelmezhetősége miatt jelen tanulmányban csak a lineáris regressziós modellek eredményét közülük.

A becsült egyenlet a Magyar Választáskutatási Panel esetében a következő volt:

$$
I_{i}=B_{0}+B_{1} F_{i}^{s}+B_{2} H_{i}^{w}+B_{3} N_{i}^{s}+B_{4} N_{i}^{w}+B_{5} X_{i}+\varepsilon_{i}
$$

ahol $I_{i}$ az adott integrációs indikátor, $N_{i}^{s}$ az erős kötések száma, $N_{i}^{w}$ a gyenge kötések száma, $F_{i}^{s}$ a rokonok aránya az erős kötések között, $H_{i}^{w}$ gyenge kötések heterogenitása, $X_{i}$ az egyéni társadalmi-gazdasági jellemzők vektora, ${ }^{18} \varepsilon_{i}$ pedig a hibatag. ${ }^{19}$

A European Quality of Life Survey használatakor a következő egyenletet becsültük:

$I_{i}=B_{0}+B_{1} N_{i}^{s}+B_{2} N_{i}^{s}+B_{3} X_{i}+\varepsilon_{i}$

ahol $I_{i}$ a szubjektív integráltság mutatója, $N_{i}^{S}$ az erős kötések száma, $F_{i}^{S}$ a rokonok aránya az erős kötések között, $X_{i}$ az egyéni társadalmi-gazdasági jellemzők vektora ${ }^{20}, \varepsilon_{i}$ pedig a hibatag. ${ }^{21}$

\section{EREDMÉNYEK}

Az eredményeket az 1. és a 2. táblázat tartalmazza. Az 1. táblázat 1-3. modelljében a közéleti részvétel mutatószámai a függő változók. A gyenge kötések nagyobb heterogenitása mindhárom esetben pozitív kapcsolatban áll a közéleti részvétellel. Amennyiben gyenge kötések heterogenitása egy szórással magasabb, az egyesületi, szervezeti tagság valószínűsége 2,5 százalékponttal, a közéleti aktivitás valószínűsége 4,1 százalékponttal, a választási részvétel valószínűsége pedig szintén 4,1 százalékponttal magasabb. Az eredmény megfelel Magee (2008) amerikai, valamint Miyata és munkatársai (2008) japán adatokon végzett elemzésével. Az okság iránya természetesen nem tisztázott: ahogy korábban jeleztük elképzelhető, hogy a civil, közéleti részvétel növeli meg a társadalom különböző csoportjai közti kapcsolatokat, de az is, hogy a heterogén kapcsolatháló jelenti az alapot a közéleti részvételhez elengedhetetlen kommunikációs készségek megszerzéséhez (Sik 2010, Susánszky-Gerő 2013).

18 A kérdezett neme, életkora, iskolai végzettsége, munkaerő-piaci státusa, egészségügyi akadályozottsága, lakóhelyének településtípusa, vagyoni helyzete (12 vagyontárggyal való rendelkezés indexe), társadalmi osztálya, jövedelme, valamint, hogy partnerrel él-e, illetve a háztartás nagysága.

19 A változók leíró statisztikáit a Függelék F1. táblázata tartalmazza.

20 A kérdezett neme, életkora, iskolai végzettsége, családi állapota, munkaerő-piaci státusa, az, hogy határozatlan vagy határozott idejű szerződéssel dolgozik/dolgozott-e, szubjektív anyagi helyzete, egészségi állapota (van-e krónikus egészségügyi problémája), háztartásának jövedelme, lakóhelyének településtípusa, a település infrastrukturális helyzete (bolt, posta, bank, kulturális létesítmények, tömegközlekedés), valamint a háztartás nagysága. 
Hipotézisünknek megfelelően minél nagyobb a rokonok aránya az erős kötések között, annál kisebb az egyesületi, szervezeti aktivitás és a közéleti aktivitás is (a rokonok arányának egy szórásnyival való emelkedése a két mutató sorrendben 2,0 százalékpontos, illetve 5,0 százalékpontos csökkenésével jár együtt), ugyanakkor a választási részvétellel nem függ össze ez a mutató. Az előbbi két esetben másokkal való együttmúködésre van szükség, míg a választási részvétel egyszeri és egyedül is végrehajtható aktus. Banfield (1958) klasszikus munkájából az a magyarázat következik, hogy azok, akiknél elsősorban a rokonok jelentik az erős kötéseket, kisebb bizalommal fordulnak a másokkal való együttmúködés felé. ${ }^{22} \mathrm{Az}$ is feltételezhető, hogy a választási részvétel mögött sokkal több esetben áll valamiféle konformizmus vagy megszokás-szerű cselekvés, mint a más közéleti részvételi esetekben, mint például egy képviselő felkeresésénél, tüntetésen való részvételnél, amelyek nagyobb mértékben igényelhetnek egyedi döntéseket, mint a rendszeres időközönként megtartott országgyűlési választások, és a társadalom kevésbé „várja el” az azokon/azokban való részvételt.

Az erős kötések száma és a gyenge kötések száma is (a választási részvétel kivételével) pozitívan függ össze a közéleti részvétel mutatóival, ami megfelel a szakirodalom fent bemutatott eredményeinek. Azaz: azok, akiknek bővebb a személyes kapcsolathálójuk, nagyobb valószínűséggel vesznek részt a közéletben, mint a kevesebb kapcsolattal rendelkező személyek. ${ }^{23} \mathrm{~A}$ civil szervezeti és a közéleti aktivitással a gyenge kötések száma, míg a választási részvétellel az erős kötések száma függ össze erősebben.

Az állami és a nem kormányzati szervezetekbe vetett bizalom kapcsán hasonló mintázatot találunk (lásd: 1. táblázat 4-5. modell): az erős kötéseken belül a rokonok magas aránya alacsonyabb bizalommal, míg az erős kötések száma magasabb bizalommal jár együtt, bár az utóbbi csak az állami intézmények esetében szignifikáns. Mindkét eredmény megfelel a várakozásainknak.

22 Ugyanakkor az is elképzelhető, hogy az egyesületi, szervezeti tagság és a közéleti részvétel eredményezi azt, hogy az erős kötések között megjelennek a családtagokon kívüli személyek is.

23 Az erős kötések számának egy szórással nagyobb értéke az egyesületi, szervezeti részvétel 2,6 százalékponttal, a közéleti aktivitás 3,0 százalékponttal, a választási részvétel 2,0 százalékponttal történő emelkedésével, míg a gyenge kötések számának hasonló mértékú változása egyúttal az egyesületi részvétel 5,5 százalékponttal, a közéleti aktivitás 4,6 százalékponttal magasabb értékével jár együtt. 
1. táblázat: Az egyéni kapcsolatháló és az integráció indikátorai közti kapcsolat, OLS

\begin{tabular}{|l|c|c|c|c|c|}
\hline & $(1)$ & $(2)$ & $(3)$ & $(4)$ & $(5)$ \\
\hline & $\begin{array}{c}\text { Egyesület, } \\
\text { szervezet } \\
\text { tagja }\end{array}$ & $\begin{array}{c}\text { Közéleti } \\
\text { aktivitás }\end{array}$ & $\begin{array}{c}\text { Részt vett a } \\
\text { 2006-os } \\
\text { választáson }\end{array}$ & $\begin{array}{c}\text { Állami } \\
\text { intézményekbe } \\
\text { vetett bizalom }\end{array}$ & $\begin{array}{c}\text { Nem kormányzati } \\
\text { szervezetekbe vetett } \\
\text { bizalom }\end{array}$ \\
\hline $\begin{array}{l}\text { Rokonok aránya az erős } \\
\text { kötések között }\end{array}$ & $-0.001^{*}$ & $-0.002^{* * *}$ & 0.000 & $-0.001^{*}$ & $-0.001^{* *}$ \\
\hline $\begin{array}{l}\text { Gyenge kötések hetero- } \\
\text { genitása }\end{array}$ & $(0.000)$ & $(0.000)$ & $(0.000)$ & $(0.001)$ & $(0.001)$ \\
\hline Erős kötések száma & $0.011^{* * *}$ & $0.002^{* * *}$ & $0.001^{* *}$ & -0.000 & -0.001 \\
\hline & $(0.006)$ & $(0.007)$ & $(0.006)$ & $(0.001)$ & $(0.001)$ \\
\hline Gyenge kötések száma & $0.010^{* * *}$ & $0.009^{* * *}$ & 0.002 & -0.000 & 0.011 \\
\hline & $(0.002)$ & $(0.003)$ & $(0.003)$ & $(0.004)$ & $(0.009)$ \\
\hline Korrigált R $R^{2}$ & 0.112 & 0.123 & 0.083 & 0.057 & $(0.004)$ \\
\hline N & 1876 & 1876 & 1855 & 1868 & 0.046 \\
\hline
\end{tabular}

A Magyar Választáskutatási Panel 2008-as adatai. Az együtthatók alatt zárójelben a robusztus standard hibák találhatók. Egyéb kontrollváltozók: nem, életkor, iskolai végzettség, partnerrel él, munkaerö-piaci státus, egészségügyi akadályozottság, településtípus, vagyoni helyzet, társadalmi osztály, háztartásnagyság, jövedelem. A jövedelem változó hiányzó értékeire dummy változók szerepeltek a modellekben.

$$
{ }^{*} p<0.10,{ }^{* *} p<0.05,{ }^{* * *} p<0.01
$$

A 2. táblázatban a függő változó a szubjektív integráltság: a rokonok erős kötések közötti aránya pozitív kapcsolatban van vele, míg az erős kötések számának becsült együtthatója szintén pozitív, de nem szignifikáns egyik modellben sem. Az előbbi eredmény megfelel a várakozásainknak: azaz a relatíve homogén, inkább családtagokból álló kapcsolatháló erősebb szubjektív integráltság-érzettel jár együtt. Ugyanakkor az eredményeket óvatosan kell kezelni, hiszen - ahogy korábban jeleztük - az adatbázisban a rendelkezésre álló egyetlen egyéni kapcsolathálóra vonatkozó kérdés elnagyolt volt.

2. táblázat: Az egyéni kapcsolatháló és a szubjektív integráltság, OLS

\begin{tabular}{|l|c|c|}
\hline & $(1)$ & $(2)$ \\
\hline & Szubjektív integráltság & Szubjektív integráltság \\
\hline Rokonok aránya az erős kötések között & $0.990^{*}$ & $1.034^{* *}$ \\
\hline Erős kötések száma & $(0.531)$ & $(0.524)$ \\
\hline & 0.284 & 0.251 \\
\hline Háztartás összjövedelme & $(0.177)$ & $(0.176)$ \\
\hline Korrigált R2 & Nem & 0.227 \\
\hline N & 0.216 & 792 \\
\hline
\end{tabular}

${ }^{*} p<0.10,{ }^{* *} p<0.05,{ }^{* * *} p<0.01$

A European Quality of Life Survey 2007-es adatai. Az együtthatók alatt zárójelben a robusztus standard hibák találhatók. Egyéb kontrollváltozók: nem, életkor, iskolai végzettség, családi állapot, munkaerő-piaci státus, határozatlan vagy határozott idejű szerződés, szubjektív anyagi helyzet, egészségi állapot, háztartás nagyság, a háztartás összjövedelme, településtípus, a település infrastrukturális helyzete (5 indikátor). A jövedelemváltozó hiányzó értékeire dummy változók szerepeltek a modellekben. 
Hipotéziseink közül a H1 hipotézisnek nem mondanak ellent az eredményeink. Ahogy az imént láthattuk, a rokonok erős kötések közti aránya a társadalmi integráció egyéb indikátoraival negatívan függ össze, míg a szubjektív integráltsággal pozitív a kapcsolata, míg a heterogén kapcsolatháló (a gyenge kötések heterogenitása) valóban pozitív kapcsolatban áll a közéleti részvétellel. Az általánosított (más emberekbe vetett) bizalommal összefüggésben nem tudtuk tesztelni a hipotézist, ugyanakkor az intézményi bizalom esetében nem találtunk kapcsolatot.

Az kapcsolatháló méretével (az erős és a gyenge kötések számával) kapcsolatos eredményeink általánosságban megfelelnek a H2 hipotézisnek: azaz kapcsolatok magasabb száma aktívabb közéleti részvétellel és az állami intézményekbe vetett magasabb bizalommal jár együtt, ugyanakkor a nem kormányzati szervezetekbe vetett bizalom és a szubjektív integráltság esetében nem találtunk összefüggést. Illusztrációnak szánt rövid elemzésünk tehát rávilágít arra, hogy az egyéni kapcsolatháló nagysága, heterogenitása vagy zártsága eltérő kapcsolatban lehet az integráció különböző mutatóival.

\section{7. ÖSSZEFOGLALÁS}

Tanulmányunk célja a társadalmi és az egyéni szinten értelmezett, szubjektív integráció, valamint az egyéni kapcsolatháló mérete és heterogenitása közti kapcsolat problémáinak felvázolása, és egy későbbi részletesebb kutatás megalapozása volt. Először röviden bemutattuk az integráció különböző indikátorait, és összefoglaltuk, hogy mit tudunk a magyarországi helyzetről az elmúlt 20-25 év távlatában.

A szakirodalmi áttekintés alátámasztja a hipotéziseinket, melyek szerint az egyéni kapcsolatháló jellemzői eltérő módon függhetnek össze a társadalmi integrációval (a bizalommal, a normakövetéssel és a közéleti, társadalmi részvétellel), valamint az egyén integráltság érzésével.

Végül, illusztratív céllal, 2007-es és 2008-as magyarországi adatfelvételeket felhasználva egy rövid elemzésben bemutattuk, hogy az erős kötések között a rokonok magas aránya alacsony közéleti részvétellel és alacsony intézményi bizalommal jár együtt, a gyenge kötések heterogenitása erőteljesebb közéleti részvétellel jár együtt, míg az egyéni kapcsolatháló nagysága jellemzően pozitívan függ össze a társadalmi integráció indikátoraival.

Ezek az eredmények megerősítik, hogy kutatási kérdésünk (milyen kapcsolatban áll az egocentrikus kapcsolathálók mérete és heterogenitása a társadalmi integráció indikátoraival?) további elemzésre érdemes. E további részletesebb elemzéseink újdonságát egyfelől az adhatja, hogy magyarországi adatokkal jellemzően a téma egyik aspektusát sem kutatták, ${ }^{24}$ másfelől nem csupán az egyes tényezők önálló hatását vizsgáljuk majd behatóbban, hanem a hatások egymáshoz való viszonyát is, amire a jelenleg rendelkezésre álló adatbázisok nem adnak lehetőséget. 


\section{HIVATKOZÁSOK}

Albert F. - Dávid B. (2003) Az emberi kapcsolatok alakulása Magyarországon a XX. század utolsó évtizedében. Budapest: Tárki.

Albert F. - Dávid B. (2007) Embert barátjáról: A barátság szociológiája. Századvég.

Albert F. - Dávid B. (2012) Az interperszonális kapcsolathálózati struktúra átrendeződése Magyarországon. In Kovách I. - Dupcsik Cs. P. Tóth T. - Takács J. (szerk.) Társadalmi integráció a jelenkori Magyarországon. Budapest: Argumentum - MTA Társadalomtudományi Kutatóközpont Szociológiai Intézet, 343-356.

Allport, G. W. (1999) Az elöítélet. Budapest: Osiris.

Angelusz R. - Tardos R. (1991a) A gyenge kötések ereje és gyengesége. In Angelusz R. - Tardos R. (szerk.) Hálózatok, stílusok, struktúrák. Budapest: ELTE Szociológiai Intézet - Magyar Közvéleménykutató Intézet, 74-99.

Angelusz R. - Tardos R. (1991b) A kapcsolathálózatok, mint kontextusok. In Angelusz R. - Tardos R. (szerk.) Hálózatok, stílusok, struktúrák. Budapest: ELTE Szociológiai Intézet - Magyar Közvéleménykutató Intézet, 33-54.

Angelusz R. - Tardos R. (1991c) A magyarországi kapcsolathálózatok néhány sajátossága. In Angelusz R. - Tardos R. (szerk.) Hálózatok, stílusok, struktúrák. Budapest: ELTE Szociológiai Intézet - Magyar Közvéleménykutató Intézet, 55-73.

Angelusz R. - Tardos R. (1998) A kapcsolathálózati erőforrások átrendeződésének tendenciái a 90-es években. In Kolosi T. - Tóth I. Gy - Vukovich Gy. (szerk.) Társadalmi riport 1998. Budapest: TÁRKI, 237-256.

Angelusz R. - Tardos R. (2003) Miért mennek el mégis? Századvég, 3-31.

Angelusz R. - Tardos R. (2005) Választási részvétel és politikai aktivitás. In Angelusz R. - Tardos R. (szerk.) Törések, Hidak, Hálók. Választói magatartás és politikai tagolódás Magyarországon. Budapest: DKMKA, 323-384.

Angelusz R. - Tardos R. (2006) Hálózatok a magyar társadalomban. In Kovách I. (szerk.) Társadalmi metszetek. Érdekek és hatalmi viszonyok, individualizáció és egyenlőtlenség a mai Magyarországon. Budapest: Napvilág kiadó, 227-252.

Angelusz R. - Tardos R. (2011) Régi és új törésvonalak, polarizáció, divergenciaspirál. In Tardos R. - Enyedi Zs. - Szabó A. (szerk.) Részvétel, képviselet, politikai változás. Budapest: Demokrácia Kutatások Magyar Központja Alapítvány, 347-382.

Banerjee, A. V. - Duflo, E. (2007) The Economic Lives of the Poor. Journal of Economic Perspectives, 21(1), 141-167. http://doi.org/10.1257/jep.21.1.141.

Banfield, E. C. (1958) The Moral Basis of a Backward Society. Glencoe, Illinois: The Free Press.

Bekkers, R. - Völker, B. - van der Gaag - M., \& Flap, H. (2008) Social Networks of Participants in Voluntary Associations. In Lin, N. Erickson, B. H. (szerk.) Social Capital: An International Research Program. Oxford: Oxford University Press, 185-205.

Brann, P. - Foddy, M. (1987) Trust and the Consumption of a Deteriorating Common Resource. The Journal of Conflict Resolution, 31(4), 615-630. http://doi.org/10.1177/0022002787031004004.

Campbell, K. E. - Lee, B. A. (1991) Name generators in surveys of personal networks. Social Networks, 13(3), $203-221$. http://doi.org/10.1016/0378-8733(91)90006-F

Cohen, J. (1999) Trust, voluntary association and workable democracy: the contemporary American discourse of civil society. In Warren, M. E. (szerk.) Democracy and Trust. Cambridge: Cambridge University Press, 208-248.

Coleman, J. S. (1990) Foundations of Social Theory. Cambridge, MA: Belknap Press of Harvard University Press.

Csepeli Gy. - Örkény A. - Székelyi M. - Barna I. (2004) Bizalom és gyanakvás. Szociálpszichológiai akadályok a piacgazdasághoz vezető úton Kelet-Európában. Szociológiai Szemle, (1), 3-35.

Diener, E. - Lucas, R. E. - Schimmack, U. - Helliwell, J. F. (2009) Well-Being for Public Policy. New York: Oxford University Press.

Dupcsik Cs. - Tóth O. (2008) Feminizmus helyett familizmus. Demográfia, 51(4), 307-328.

EVS (2011) European Values Study 2008: Integrated Dataset (EVS 2008). GESIS Data Archive, Cologne. ZA4800 Data file Version 3.0.0, http://doi.org/10.4232/1.11004.

Gerő M. (2012a) A civil társadalom néhány trendje Magyarországon 1990 után. In Kovách I. - Dupcsik Cs. - P. Tóth T. - Takács J. (szerk.) Társadalmi integráció a jelenkori Magyarországon. Budapest: Argumentum - MTA Társadalomtudományi Kutatóközpont Szociológiai Intézet, 317-342.

Gerő M. (2012b) A személyközi kapcsolatok szerkezete- Kutatási eredmények, irányok Angelusz Róbert munkássága nyomán. In Gerő M. - Fonyó A. - Petényi M. - Szabó F. (szerk.) A nyilvánosság elemzésétöl a választáskutatásig - Tanulmányok Angelusz Róbert emlékére. Budapest: ELTE Angelusz Róbert Társadalomtudományi Szakkollégium, 24-50.

Giczi J. - Sik E. (2009) Bizalom, társadalmi tőke, intézményi kötődés. In Tóth I. Gy. (szerk.), Tárki Európai Társadalmi Jelentés. Budapest: Tárki, 65-84.

Granovetter, M. (1973) The Strength of Weak Ties. American Journal of Sociology, 78(6), 1360-1380. http://doi.org/10.1086/225469. 
Granovetter, M. (1983) The Strength of Weak Ties: A Network Theory Revisited. Sociological Theory, 1, 201-233. http://doi.org/10.2307/202051.

Hajdu G. (2012) Bizalom, normakövetés és társadalmi részvétel Magyarországon a rendszerváltás után. In Kovách I. - Dupcsik Cs. - P. Tóth T. - Takács J. (szerk.) Társadalmi integráció a jelenkori Magyarországon. Budapest: Argumentum - MTA Társadalomtudományi Kutatóközpont Szociológiai Intézet, 45-62.

Hermes, N. - Lensink, R. (2007) The empirics of microfinance: what do we know? Economic Journal, 117(517), F1-F10. http://doi.org/10.1111/j.1468-0297.2007.02013.x.

Cohen, J. L. - Arato, A. (1992) Civil Society and Political Theory. Cambridge: MIT Press.

Karlan, D. S. (2007) Social connections and group banking. Economic Journal, 117(2), F52-F84. http://doi.org/10.1111/j.1468-0297.2007.02015.x.

Kmetty Z. (2012) Politikai diskurzus és participáció. In Gerő M. - Fonyó A. - Petényi M. - Szabó F. (szerk.) A nyilvánosság elemzésétől a választáskutatásig - Tanulmányok Angelusz Róbert emlékére. Budapest: ELTE Angelusz Róbert Társadalomtudományi Szakkollégium, 63-93.

Laumann, E. O. (2006) A 45-year Retrospective on Doing Networks. Connections, 27, 65-90. http://doi.org/10.1.1.211.8478.

Lin, N. (1991) Társadalmi erőforrások és társadalmi mobilitás. A státuselérés strukturális elmélete. In Angelusz R. - Tardos R. (szerk.) Társadalmak rejtett hálózata (pp.). Budapest: Magyar Közvéleménykutató Intézet, 23-53.

Lin, N. (1999) Social Networks and Status Attainment. Annual Review of Sociology, 25, 467-487. http://doi.org/10.1146/annurev. soc.25.1.467

Lin, N. - Fu, Y. - Hsung, R.-M. (2001) The Position Generator. In Lin, N. - Cook, K. - Burt, R. S. (szerk.) Social Capital: Theory and Research. New York: Aldine de Gruyter, 57-81.

Magee, M. P. (2008) Civic Participation and Social Capital: A Social Network Analysis in Two American Counties. In Lin., N. - Erickson, B. H. (szerk.) Social Capital: An International Research Program. Oxford: Oxford University Press, 308-327.

Marsden, P. V. (2005) Recent Developments In Network Measurement. In Carrington, P. J. - Scott, J. - Wasserman, S. (szerk.) Models And Methods In Social Network Analysis. New York: Cambridge University Press, 8-30.

Messick, D. M. - Wilke, H. - Brewer, M. B. - Kramer, R. M. - Zemke, P. E. - Lui, L. (1983) Individual adaptations and structural change as solutions to social dilemmas. Journal of Personality and Social Psychology, 44(2), 294-309. http://doi.org/10.1037/0022-3514.44.2.294.

Miyata, K. - Ikeda, K. - Kobayashi, T. (2008) The Internet, Social Capital, Civic Engagement, and Gender in Japan. In Lin, N. - Erickson, B. H. (szerk.) Social Capital: An International Research Program. Oxford: Oxford University Press, 206-233.

Mutz, D. C. (2002) The Consequences of Cross-Cutting Networks for Political Participation, American Journal of Political Science, 46(4), 838-855. http://doi.org/10.2307/3088437.

Nárai M. (2004) A civil szervezetek szerepe és jelentőségük. Educatio, 13(4), 616-634.

Noelle-Neumann, E. (2007) A hallgatásspirál elmélete In Angelusz R. - Tardos R. - Terestyéni T. (szerk.) (2007): Média, nyilvánosság, közvélemény - Szöveggyüjtemény. Budapest: Gondolat, 776-800.

Pentland, A. (2014) Social Physics: How Good Ideas Spread - The Lessons from a New Science. New York: The Penguin Press.

Pichler, F. - Wallace, C. (2008) Social Capital and Social Class in Europe: The Role of Social Networks in Social Stratification. European Sociological Review, 25, 319-332. http://doi.org/10.1093/esr/jcn050.

Putnam, R. D. (2000) Bowling Alone: The Collapse and Revival of American Community. New York: Simon \& Schuster.

Putnam, R. D. - Leonardi, R. - Nanetti, R. Y. (1993) Making Democracy Work. Princeton, New Yersey: Princeton University Press.

Sengupta, R. - Aubuchon, C. P. (2008) The Microfinance Revolution: An Overview. Federal Reserve Bank of St. Louis Review, 90(1), 9-30.

Sik D. (2010) A network-heterogenitás, a kommunikatív racionalitás és az állampolgári aktivitás empirikus összefüggései. In Utasi Á. (szerk.) Közösség és közélet. Budapest - Szeged: MTA Politikatudományi Intézet - Szegedi Tudományegyetem BTK Szociológia Tanszék - Belvedere Kiadó, 31-44.

Skvoretz, J. (2013) Diversity, Integration, and Social Ties: Attraction versus Repulsion as Drivers of Intra- and Intergroup Relations. American Journal of Sociology, 119, 486-517. http://doi.org/10.1086/674050.

Susánszky P. - Gerő M. (2013) A civil részvételt segítő és gátló tényezőkről. In Susánszky É. - Szántó Z. (szerk.) Magyar lelkiállapot 2013. Budapest: Semmelweis Kiadó, 25-42

Tocqueville, A. (1993) Az amerikai demokrácia. Budapest: Európa Könyvkiadó, 25-40. 
Tóth I. Gy. (2009) Bizalomhiány, normazavarok, igazságtalanságérzet és paternalizmus a magyar társadalom értékszerkezetében. A gazdasági felemelkedés társadalmi-kulturális feltételei címü kutatás zárójelentése. Budapest: Tárki.

Tyler, T. R. - Degoey, P. (1995) Collective Restraint in Social Dilemmas: Procedural Justice and Social Identification Effects on Support for Authorities. Journal of Personality and Social Psychology, 69(3), 482-497. http://doi.org/10.1037/0022-3514.69.3.482.

Utasi Á. (1991) Az interperszonális kapcsolatok néhány nemzeti sajátosságáról. In Utasi Á. (szerk.) Társas kapcsolatok. Budapest: Gondolat, 169-193.

Utasi Á. (2013) Kötelékben. Szolidaritás-hálók és közélet. Szeged: MTA Társadalomtudományi Kutatóközpont - Belvedere.

Wollebaek, D. - Selle, P. (2002) Does Participation in Voluntary Associations Contribute to Social Capital? The Impact of Intensity, Scope, and Type. Nonprofit and Voluntary Sector Quarterly, 31(1), 32-61. http://doi.org/10.1177/0899764002311002. 


\section{FÜGGELÉK}

F1. táblázat: A felhasznált változók leíró statisztikái, Magyar Választáskutatási Panel

\begin{tabular}{|l|c|c|c|c|c|}
\hline & Átlag & Szórás & Min & Max & $N$ \\
\hline Rokonok aránya az erös kötések között & 74.329 & 30.457 & 0 & 100 & 2013 \\
\hline Gyenge kötések heterogenitása & 48.345 & 19.156 & 1 & 154.3 & 2048 \\
\hline Erős kötések száma & 3.138 & 1.843 & 0 & 12 & 2120 \\
\hline Gyenge kötések száma & 11.190 & 5.187 & 0 & 24 & 2117 \\
\hline Egyesület, szervezet tagja & 0.204 & 0.403 & 0 & 1 & 2119 \\
\hline Közéleti aktivitás & 0.255 & 0.436 & 0 & 1 & 2119 \\
\hline Részt vett a 2006-os választáson & 0.759 & 0.428 & 0 & 1 & 2091 \\
\hline Állami intézményekbe vetett bizalom & 2.518 & 0.565 & 1 & 4 & 2101 \\
\hline Nem kormányzati szervezetekbe vetett bizalom & 2.200 & 0.609 & 1 & 4 & 2036 \\
\hline Életkor & 47.855 & 17.899 & 18 & 96 & 2112 \\
\hline Partnerrel él & 0.584 & 0.493 & 0 & 1 & 2116 \\
\hline Nem & 1.542 & 0.498 & 1 & 2 & 2120 \\
\hline Legfeljebb általános iskola & 0.244 & 0.430 & 0 & 1 & 2116 \\
\hline Szakiskola, szakmunkásképzó & 0.320 & 0.466 & 0 & 1 & 2116 \\
\hline Érettségi & 0.299 & 0.458 & 0 & 1 & 2116 \\
\hline Diploma & 0.138 & 0.345 & 0 & 1 & 2116 \\
\hline Budapest & 0.168 & 0.374 & 0 & 1 & 2120 \\
\hline Megyeszékhely & 0.213 & 0.409 & 0 & 1 & 2120 \\
\hline Város & 0.285 & 0.452 & 0 & 1 & 2120 \\
\hline Község & 0.334 & 0.472 & 0 & 1 & 2120 \\
\hline Felső osztály & 0.022 & 0.146 & 0 & 1 & 2094 \\
\hline Középosztály & 0.403 & 0.491 & 0 & 1 & 2094 \\
\hline Alsó-középosztály & 0.262 & 0.440 & 0 & 1 & 2094 \\
\hline Alsó- és munkásosztály & 0.313 & 0.464 & 0 & 1 & 2094 \\
\hline Dolgozik & 0.510 & 0.500 & 0 & 1 & 2111 \\
\hline Nyugdijas & 0.330 & 0.470 & 0 & 1 & 2111 \\
\hline Munkanélküli & 0.048 & 0.214 & 0 & 1 & 2111 \\
\hline Tanuló & 0.064 & 0.244 & 0 & 1 & 2111 \\
\hline Egyéb munkaeró-piaci státusz & 0.048 & 0.213 & 0 & 1 & 2111 \\
\hline Vagyoni helyzet & 7.442 & 2.979 & 0 & 12 & 2086 \\
\hline Egészségügyi akadályozottság & 0.241 & 0.428 & 0 & 1 & 2110 \\
\hline Háztartásnagyság & 2.803 & 1.236 & 1 & 5 & 2118 \\
\hline Egyéni jövedelem & 89026 & 80244 & 11000 & 1140000 & 1338 \\
\hline & & & & \\
\hline
\end{tabular}


F2. táblázat: A felhasznált változók leíró statisztikái, European Quality of Life Survey

\begin{tabular}{|c|c|c|c|c|c|}
\hline & Átlag & Szórás & Min & Max & $\mathrm{N}$ \\
\hline Szubjektív integráltság & 14.763 & 3.445 & 4 & 20 & 902 \\
\hline Rokonok aránya az erős kötések között (\%) & 0.795 & 0.267 & 0 & 1 & 992 \\
\hline Erős kötések száma & 4.314 & 0.887 & 0 & 5 & 1000 \\
\hline Nem & 0.536 & 0.499 & 0 & 1 & 1000 \\
\hline Életkor & 46.479 & 17.694 & 18 & 95 & 1000 \\
\hline Alapfokú végzettség & 0.553 & 0.497 & 0 & 1 & 1000 \\
\hline Középfokú végzettség & 0.332 & 0.471 & 0 & 1 & 1000 \\
\hline Felsőfokú végzettség & 0.115 & 0.319 & 0 & 1 & 1000 \\
\hline Házas vagy élettárssal él & 0.620 & 0.486 & 0 & 1 & 993 \\
\hline Elvált vagy különvált & 0.088 & 0.283 & 0 & 1 & 993 \\
\hline Özvegy & 0.110 & 0.312 & 0 & 1 & 993 \\
\hline Egyedülálló & 0.183 & 0.387 & 0 & 1 & 993 \\
\hline Dolgozik & 0.457 & 0.498 & 0 & 1 & 1000 \\
\hline Nyugdíjas & 0.315 & 0.465 & 0 & 1 & 1000 \\
\hline Munkanélküli & 0.075 & 0.264 & 0 & 1 & 1000 \\
\hline Tanuló & 0.058 & 0.234 & 0 & 1 & 1000 \\
\hline Egyéb munkaerő-piaci státusz & 0.095 & 0.293 & 0 & 1 & 1000 \\
\hline Község & 0.535 & 0.499 & 0 & 1 & 999 \\
\hline Város & 0.280 & 0.449 & 0 & 1 & 999 \\
\hline Budapest & 0.185 & 0.388 & 0 & 1 & 999 \\
\hline Háztartásnagyság & 2.976 & 1.247 & 1 & 5 & 1000 \\
\hline Krónikus egészségügyi probléma & 0.287 & 0.452 & 0 & 1 & 976 \\
\hline Könnyen kijönnek a jövedelmükből & 0.254 & 0.436 & 0 & 1 & 992 \\
\hline Elég nehezen jönnek ki a jövedelmükből & 0.379 & 0.485 & 0 & 1 & 992 \\
\hline Nehezen jönnek ki a jövedelmükből & 0.206 & 0.405 & 0 & 1 & 992 \\
\hline Nagyon nehezen jönnek ki a jövedelmükből & 0.161 & 0.367 & 0 & 1 & 992 \\
\hline Határozatlan idejú szerződése van (volt) & 0.818 & 0.386 & 0 & 1 & 936 \\
\hline Élelmiszerbolt elérhető & 0.942 & 0.235 & 0 & 1 & 997 \\
\hline Postahivatal elérhető & 0.848 & 0.359 & 0 & 1 & 998 \\
\hline Banki szolgáltatások elérhetőek & 0.771 & 0.420 & 0 & 1 & 982 \\
\hline Kulturális intézmények elérhetőek & 0.636 & 0.481 & 0 & 1 & 982 \\
\hline Tömegközlekedési lehetőségek elérhetőek & 0.882 & 0.323 & 0 & 1 & 995 \\
\hline Háztartás jövedelme (EUR) & 668.1 & 474.7 & 25.5 & 4724.5 & 742 \\
\hline
\end{tabular}

